\title{
TEMPAT PELATIHAN INDUSTRI KONVEKSI : TIPOLOGI BARU SEBAGAI PENDEKATAN DISAIN
}

\author{
Alifia lufthansa ${ }^{1)}$, Suwandi Supatra²) \\ 1) Program Studi S1 Arsitektur, Fakultas Teknik, Universitas Tarumanagara, alifialuf@gmail.com \\ 2) Program Studi S1 Arsitektur, Fakultas Teknik, Universitas Tarumanagara,ybhan50@gmail.com
}

\begin{abstract}
Abstrak
Bonus Demografi dan Revolusi Industri 4.0 nampaknya menjadi isu yang saat ini sedang difokuskan pemerintah. Bonus Demografi menjadi peluang bagi Indonesia jika dipersiapkan dengan baik karena penduduk usia produktif ini dapat menanggung usia non produktif. Saat ini pemerintah fokus di industri yang menjadi pendorong perkembangan revolusi industri 4.0, yakni makanan dan minuman, elektronik, otomotif, tekstil, dan kimia. Salah satu upaya yang dapat dilakukan adalah membuat wadah pelatihan bagi penduduk usia produktif (millenial). Target tempat pelatihan ini adalah usia produktif yang belum bekerja, usia produktif yang sudah bekerja namun ingin meningkatkan skillnya, masyarakat awam yang membutuhkan pembekalan ilmu dan keterampilan di bidang tersebut. Lokasi proyek terpilih memiliki kualifikasi sebagai berikut : merupakan kawasan industri besar, kepadatan penduduk dengan usia produktif yang tinggi, banyaknya usia produktif yang menjadi pengangguran. Dari kualifikasi tersebut terpilihlah kawasan Cakung yang menjadi lokasi proyek. Tapak berada di Cakung Barat Jakarta Timur. Di Cakung sendiri sudah terdapat Jakarta Industrial Estate Pulogadung (JIEP) dan Perkampungan Industri Kecil (PIK) Pulogadung yang masih eksis sampai sekarang. Menurut data yang diperoleh, industri konveksi paling banyak terdapat di wilayah Cakung. Sehingga tempat pelatihan ini dikonsentrasikan untuk industri konveksi.
\end{abstract}

Kata kunci: Bonus Demografi; Revolusi Industri 4.0; Tempat Pelatihan

\begin{abstract}
Demographic Dividend and Industrial Revolution 4.0 seems to be a problem currently being faced of the government. Demographic Dividend is an opportunity for Indonesia if it is well prepared because this productive age population can sustain non-productive age. At present the government focuses on industries that are driving the development of the industrial revolution 4.0, especially food and beverages, electronics, automotive, textiles and chemicals. One effort that can be done is to make training for the productive age population (millennial). The target of this training place is the productive age who have not worked, productive age who have worked but want to improve their skills, lay people who need the provision of knowledge and skills in the field. The selected project locations have the following qualifications: representing large industrial estates, densely populated populations with high productive ages, the number of productive ages who are winners. From these qualifications, the Cakung area was chosen as the project location. Tread is in Cakung Barat, East Jakarta. In Cakung itself Jakarta Industrial Estate Pulogadung (JIEP) and the Perkampungan Industri Kecil (PIK) still exist today. According to the data obtained, the convection industry is mostly found in the Cakung region. For this training place to concentrate on the industrial convection.
\end{abstract}

Keywords: Demographic Dividend; Industrial Revolution 4.0; Training Space

\section{PENDAHULUAN}

\section{Latar Belakang}

Marilah kita mengenal Indonesia lewat data. Banyak yang memprediksi kondisi Indonesia dengan berbagai pendekatan. Akan tetapi pendekatan yang berbasis data, fakta yang terukur akan memudahkan kita memahami kondisi secara objektif. Salah satu fakta yang harus kita dekati dengan data dan fakta yang objektif adalah mengenai masalah bonus demografi Indonesia yang diprediksi akan datang di tahun 2020-2030 dan era revolusi industri 4.0. Apa dan bagaimana di tahun 2020 akan terjadi, tentu harus dipahami dengan pendekatan data dan fakta yang valid, statistik yang terukur. Kesalahan mengungkap data dan fakta tentu akan menimbulkan rasa pesimis atau bahkan salah dalam menyikapi. 
Indonesia termasuk dalam empat besar negara yang berpenduduk terbanyak di dunia. Dengan jumlah penduduk sekitar 258 juta jiwa, hingga kini Indonesia hanya berada di peringkat kelima dalam hal kemakmuran di ASEAN. Tentu saja Indonesia menginginkan perubahan dan kemajuan ekonomi, dan salah satu harapannya adalah dari adanya bonus demografi di Indonesia. Tahun puncak bonus demografi di Indonesia diperkirakan akan terjadi pada tahun 2020-2030. Sebelum memasuki tahun tersebut, tentu saja kita sudah dapat melihat perkembangannya pada saat ini.

Menyambut tahun 2020-2030 sebagai puncak tahun bonus demografi di Indonesia tentunya adalah menyambut peluang yang sangat besar untuk kemajuan dan pertumbuhan ekonomi di Indonesia. Sebelum memasuki tahun 2020, Generasi Millenials sebagai populasi atau kelompok umur yang akan menjadi bonus ini sudah menunjukkan keunggulan dan kehebatannya melalui aksi nyata, khususnya pengoptimalan teknologi dan digital. Dengan adanya generasi millenials yang terus tumbuh dan berkembang, akan ada banyak manfaat khususnya dalam bidang ekonomi yang akan didapatkan oleh Indonesia. Salah satu dampak terbesarnya adalah semakin minimnya pengangguran dan terbukanya banyak lahan pekerjaan baru bagi masyarakat Indonesia, yang bisa jadi tidak ada lahannya di masa-masa sebelumnya.

Era Revolusi Industri keempat sebenarnya sedang Indonesia tapaki yang ditandai dengan digitalisasi. Contohnya, dari sistem belanja daring sampai pembayaran uang elektronik ( $e$ money). Tak hanya itu, perubahan di dunia digital begitu marak terjadi di nusantara. Populasi penduduk Indonesia saat ini mencapai 262 juta orang. Lebih dari 50 persen atau sekitar 143 juta orang telah terhubung jaringan internet sepanjang 2017, setidaknya begitu menurut laporan teranyar Asosiasi Penyelenggara Jasa Internet Indonesia (APJII). Sekarang adalah bagaimana kita merubah mindset kita dengan revolusi 4.0 ini, dan bagaimana teamwork kita dalam bekerja. Jadi bagaimana kita menyikapi perkembangan teknologi 4.0 itu yang begitu cepat. Bagaimana pula cara membuat manajemen yang rapi dan teamwork yang rapi. Sekarang, apabila dikaitkan dengan teknologi 4.0, karena teknologi ini kalau kita tidak paham, nanti masing-masing akan lari kemana-mana," terang Luhut B. Pandjaitan.

Menghadapi revolusi industri 4.0, Pemerintah Indonesia melalui Kementerian Perindustrian telah mencanangkan "Making Indonesia 4.0" sebagai upaya merumuskan peta jalan atau roadmap mengenai strategi Indonesia dalam memasuki fase industri yang baru. Saat ini pemerintah fokus di industri yang jadi pendorong perkembangan revolusi industri 4.0, yakni makanan dan minuman, elektronik, otomotif, tekstil, dan kimia.

\section{Visi dan Misi}

Visi dari program ini adalah menjadi tempat pelatihan yang berkualitas, professional, dan produktif.

Adapun misi dari program ini adalah membentuk dan menciptakan Tenaga Kerja / kaum millenial yang mandiri, berkualitas, professional, produktif, dan memiliki etos kerja yang tinggi sesuai dengan pasar kerja.

\section{Studi Kelayakan Proyek}

Aspek budaya, ekonomi, dan sosial yaitu menyangkut dampak yang diberikan kepada masyarakat sekitar karena adanya usaha kegiatan tersebut, seperti :

a. Dari sisi budaya : Dampak keberadaan proyek terhadap kehidupan masyarakat, kebiasaan adat setempat (banyaknya pabrik dan pekerja pabrik di sekitar Lokasi Proyek).

b. Dari sisi ekonomi : Seberapa besar tingkat pendapatan penduduk per kapita, apakah proyek dapat mengubah atau justru mengurangi income per kapita penduduk setempat, pendapatan nasional, atau upah rata-rata tenaga kerja setempat.

c. Dari sisi sosial : Dengan adanya proyek apakah akan semakin ramai, lalu lintas semakin lancar, adanya jalur komunikasi, penerangan listrik dan lainnya, apakah berpengaruh pada pendidikan bermasyarakat. 
Menurut Husnan dan Suwarsono (2000), studi kelayakan proyek merupakan penelitian tentang dapat tidaknya suatu proyek dilaksanakan dengan berhasil yang menyangkut 3 aspek :

a. Manfaat ekonomis proyek : Bagi proyek itu sendiri, apakah proyek cukup menguntungkan atau tidak dibandingkan dengan resiko proyek.

b. Manfaat bagi negara dimana proyek dilaksanakan secara ekonomi makro.

c. Manfaat sosial proyek bagi masyarakat sekitar seperti penyerapan tenaga kerja, peningkatan output yang dihasilkan, penghematan atau penambahan devisa.

\section{KAJIAN LITERATUR :}

\section{Pengertian Millenials}

Millennials atau kadang juga disebut dengan generasi $Y$ adalah sekelompok orang yang lahir setelah Generasi X, yaitu orang yang lahir pada kisaran tahun 1980- 2000an. Maka ini berarti millenials adalah generasi muda yang berumur 17- 37 pada tahun ini. Millennials sendiri dianggap spesial karena generasi ini sangat berbeda dengan generasi sebelumnya, apalagi dalam hal yang berkaitan dengan teknologi.

Generasi millennials memiliki ciri khas tersendiri yaitu, mereka lahir pada saat TV berwarna,handphone juga internet sudah diperkenalkan. Sehingga generasi ini sangat mahir dalam teknologi. Di Indonesia sendiri dari jumlah 255 juta penduduk yang telah tercatat, terdapat 81 juta merupakan generasi millenials atau berusia 17- 37 tahun. Hal ini berarti Indonesia memiliki banyak kesempatan untuk membangun negaranya.

Sungguh tidak, jika kita melihat ke dunia sosial media, generasi millennials sangat mendominasi jika dibandingkan dengan generasi $X$. Dengan kemampuannya di dunia teknologi dan sarana yang ada, generasi millenials belum banyak yang sadar akan kesempatan dan peluang di depan mereka. Generasi millennials cenderung lebih tidak peduli terhadap keadaan sosial di sekitar mereka seperti dunia politik ataupun perkembangan ekonomi Indonesia. Kebanyakan dari generasi millenials hanya peduli untuk membanggakan pola hidup kebebasan dan hedonisme. Memiliki visi yang tidak realistis dan terlalu idealistis, yang penting bisa gaya.

\section{Karakter Millennials}

Beberapa karakter khas yang dimiliki generasi millennials adalah :

a. Senang berkolaborasi

Millennials tumbuh dalam budaya berbagi. Mereka tidak merespons kampanye pemasaran hard selling. Sebaliknya, mereka senang menjadi pencipta produk (product cocreator) dan terlibat dalam pengembangan produk maupun layanan. Perusahaan umumnya menginginkan produk tersebut dikonsumsi. Namun tidak dengan millennials, keterlibatan pada pengembangan produk membuat mereka lebih percaya dan loyal terhadap brand.

b. Generasi yang kreatif

Hal yang perlu dibanggakan adalah bahwa generasi ini sangat - sangat kreatif. Berpikir dengan sangat kritis, juga mampu memberikan - memberikan gagasan/solusi terhadap permasalahan yang ada di sekitar.

c. Mandiri dan suka berwirausaha

Karena mempunyai pemikiran - pemikiran yang kreatif, maka generasi ini banyak yang memilih untuk berwirausaha dan menjadi bos dalam bisnisnya sendiri sehingga bisa dikatakan mandiri.

d. Pendidikan nomor 1 tapi banyak pengangguran

Generasi ini mengutamakan pendidikan, sebagian besarnya fokus kuliah dulu dibandingkan langsung kerja. Menjadi tren juga bahwa justru berlomba meraih gelar 
tertinggi, tidak hanya untuk S1, melainkan juga untuk S2 dan bahkan untuk S3. Namun banyak juga yang pengangguran walaupun telah mengenyam pendidikan tingkat tinggi.

Ada 2 faktor penyebabnya:

a. Tidak mau bekerja di kantor atau lebih memilih bekerja paruh waktu

b. Tidak bekerja untuk pekerjaan yang sesuai dengan keterampilannya

\section{Tipe dan Perilaku Dalam Arsitektur}

Kata tipe memberikan gambaran tentang rangkaian dari model, jenis, dan karakter lainnya. Tipe dalam bahasa Inggris 'type' dan dalam bahasa Yunani Typos berarti model, matriks, jejak, pada sebuah figur yang membawa karakter asal yang berhubungan erat dengan hukum Universal. Arsitektur bukan hanya dideskripsikan melalui tipe, tetapi juga dihasilkan melaluinya. Tipe dan perilaku memiliki relasi timbal balik dalam arsitektur. Berinteraksi dan menghasilkan perubahan pada keduanya sedikit demi sedikit. Perilaku adalah cara seseorang atau sesuatu bertindak terhadap subjek atau objek lain disekitarnya.

Dalam buku Behaviorology, Tsukamoto dan Kaijima membagi perilaku ke dalam tiga kategori tersebut (manusia, alam, dan bangunan). Perilaku bangunan adalah bentuk respon terhadap perilaku manusia dana lam, serta berbagai perilaku sosial, budaya, dan ekonomi. Kedua bentuk interaksi antara tipe dan perilaku menggambarkan peran arsitektur sebagai ekosistem perilaku yang kompleks. Ekosistem perilaku menampung berbagai kategori perilaku dalam suatu tempat. Arsitektur bukan hanya menjadi media yang menunjukkan perilaku tetapi juga wadah yang menampung dinamika perilaku di dalam dan sekitarnya.

\section{Teori Hierarchy of Needs}

Abraham Maslow dikenal sebagai pelopor aliran psikologi humanistik. Maslow percaya bahwa manusia tergerak untuk memahami dan menerima dirinya sebisa mungkin. Teorinya yang sangat terkenal sampai dengan hari ini adalah teori tentang Hierarchy of Needs atau hirarki kebutuhan. Psikolog humanis percaya bahwa setiap orang yang memiliki keinginan yang kuat untuk merealisasikan potensi-potensi dalam dirinya, untuk mencapai tingkatan aktualisasi diri. Hal ini menggambarkan bahwa manusia baru dapat mengalami "puncak pengalamannya" saat manusia tersebut selaras dengan dirinya maupun sekitarnya. (Wikipedia, 2017).

\section{Hirarki kebutuhan}

Adapun hierarki kebutuhan tersebut adalah sebagai berikut :

a. Kebutuhan fisiologis atau dasar

b. Kebutuhan akan rasa aman

c. Kebutuhan untuk dicintai dan disayangi

d. Kebutuhan untuk dihargai

e. Kebutuhan untuk aktualisasi diri

Moslow menyebut empat kebutuhan mulai dari kebutuhan fisiologis sampai kebutuhan harga diri dengan sebutan homeostatis. Kemudian berhenti dengan sendirinya. Maslow memperluas cakupan prinsip homeostatik ini kepada kebutuhan-kebutuhan tadi, seperti rasa aman, cinta, dan harga diri yang biasanya tidak kita kaitkan dengan prinsip tersebut. Maslow menganggap kebutuhan-kebutuhan defisit tadi sebagai kebutuhan untuk bertahan. Cinta dan kasih sayang pun sebenarnya memperjelas kebutuhan ini sudah ada sejak lahir persis sama dengan insting.

a. Kebutuhan fisiologis atau dasar

Pada tingkat yang paling bawah, terdapat kebutuhan yang bersifat fisiologik (kebutuhan akan udara, makanan, minuman dan sebagainya) yang ditandai oleh kekurangan (defisi) 
sesuatu dalam tubuh orang yang bersangkutan. Kebutuhan ini dinamakan juga kebutuhan dasar (basic needs) yang jika tidak dipenuhi dalam keadaan yang sangat ekstrem (misalnya kelaparan) bisa menyebabkan manusia yang bersangkutan kehilangan kendali atas perilakunya sendiri karena seluruh kapasitas manusia tersebut dikerahkan dan dipusatkan hanya untuk memenuhi kebutuhan dasarnya itu. Sebaliknya, jika kebutuhan dasar ini relatif sudah tercukupi, muncullah kebutuhan yang lebih tinggi yaitu kebutuhan akan rasa aman (safety needs).

b. Kebutuhan akan rasa aman

Jenis kebutuhan yang kedua ini berhubungan dengan jaminan keamanan, stabilitas, perlindungan, struktur, situasi yang bisa diperkirakan, bebas dari rasa takut, cemas dan sebagainya. Karena adanya kebutuhan inilah maka manusia membuat peraturan, undangundang, mengembangkan kepercayaan, membuat sistem, asuransi, pensiun, dan sebagainya. Sama halnya dengan basic needs ini terlalu lama dan terlalu banyak tidak terpenuhi, maka pandangan seseorang tentang dunianya bisa terpengaruh dan pada gilirannya pun perilakunya akan cenderung ke arah yang makin negatif.

c. Kebutuhan dicintai dan disayangi

Setelah kebutuhan dasar dan rasa aman relatif dipenuhi, maka timbul kebutuhan untuk dimiliki dan dicintai. Setiap orang ingin mempunyai hubungan yang hangat dan akrab, bahkan mesra dengan orang lain. la ingin mencintai dan dicintai. Setiap orang ingin setiakawan dan butuh kesetiakawanan. Setiap orang pun ingin mempunyai kelompoknya sendiri, ingin punya "akar" dalam masyarakat. Setiap orang butuh menjadi bagian dalam sebuah keluarga, sebuah kampung, suatu marga, dll. Setiap orang yang tidak mempunyai keluarga akan merasa sebatang kara, sedangkan orang yang tidak sekolah dan tidak bekerja akan merasa dirinya pengangguran yang tidak berharga. Kondisi seperti ini akan menurunkan harga diri orang yang bersangkutan.

d. Kebutuhan harga diri

Di sisi lain, jika kebutuhan tingkat tiga relatif sudah terpenuhi, maka timbul kebutuhan akan harga diri. Pertama, adalah kebutuhan-kebutuhan akan kekuatan, penguasaan, kompetensi, percaya diri, dan kemandirian. Sedangkan yang kedua adalah kebutuhan akan penghargaan dari orang lain, status, ketenaran, dominasi, kebanggaan, dianggap penting dan apresiasi dari lain . Orang - orang yang terpenuhi kebutuhannya akan harga diri akan tampil sebagai orang yang percaya diri, tidak tergantung pada orang lain dan selalu siap untuk berkembang terus untuk selanjutnya meraih kebutuhan yang tertinggi yaitu aktualisasi diri (self actualization).

e. Kebutuhan aktualisasi diri

Kebutuhan aktialisasi diri merupakan kebutuhan yang terdapat 17 meta kebutuhan yang tidak tersusun secara hirarki, melainkan saling mengisi. Jika berbagai meta kebutuhan tidak terpenuhi maka akan terjadi meta patologi seperti apatisme, kebosanan, putus asa, tidak punya rasa humor lagi, keterasingan, mementingkan diri sendiri, kehilangan selera, dan sebagainya.

\section{Sumber Daya Manusia}

Hasibuan (2003, h 244) menyebutkan bahwa pengertian Sumber Daya Manusia adalah kemampuan terpadu dari daya pikir dan daya fisik yang dimiliki individu. Pelaku dan sifatnya di lakukan oleh keturunan dan lingkungannya, sedangkan prestasi kerjanya dimotivasi oleh keinginan untuk memenuhi kepuasannya. Menurut Pigors dan Myers, pelatihan merupakan upaya untuk pengembangan sumber daya manusia. Pelatihan lebih berkaitan dengan peningkatan kemampuan atau keterampilan kerja yang sudah menduduki suatu jabatan tertentu. 


\section{Pendidikan non formal}

Pendidikan non formal adalah jalur pendidikan diluar pendidikan formal yang dapat melaksanakan secara struktur dan berjenjang. Hasil pendidikan non formal dapat dihargai setara hasil pendidikan formal setelah melalui proses penilaian penyerataan oleh Lembaga yang ditunjuk oleh pemerintah/daerah dengan mengacu pada Standar Nasional Pendidikan Menurut Departemen Pendidikan Nasional, pendidikan nonformal meliputi :
a. Lembaga Kursus
b. Lembaga Pelatihan
c. Kelompok Belajar
d. Pusat kegiatan belajar masyarakat
e. Majelis Hakim serta satuan pendidikan yang sejenis

Kursus dilakukan bagi masyarakat yang memerlukan bekal pengetahuan, keterampilan, kecakapan hidup dan sikap untuk mengembangkan diri, pengembangan profesi, bekerja, usaha mandiri, dan melanjutkan pendidikan ke jenjang yang lebih tinggi.

\section{METODE :}

Metode / cara yang digunakan dalam perencanaan dan perancangan yaitu :

a. Descriptive and documentative method yaitu mengamati dan merekam konteks lingkungan, bangunan sekitar tapak, serta kebutuhan masyarakat sesuai dengan karakternya dipandang dari sudut arsitektural.

b. Case study research yaitu survey lapangan untuk mendapatkan data primer mengenai topik yang dibahas.

c. Studi literature yaitu mendapatkan kajian teoritis dan data sekunder berupa studi kepustakaan terkait proyek, kondisi lingkungan, standar ruang serta pengumpulan data informasi dan peta dari instansi terkait.

Pendekatan yang dilakukan pada program perencanaan dan perancangan proyek meliputi:

a. Aspek fungsional (kegunaan / manfaat) yaitu memahami fungsi / kegunaan proyek dalam menemukan prinsip maupun kriteria dalam menyusun, menata, mengolah fungsi ruang, tapak, bangunan. Terdiri dari :

- Judul proyek (cakupan fungsi proyek dan fungsi yang perlu difasilitasi)

- Lokasi proyek (karakter lingkungan proyek)

- Tema proyek (spesifik dari tema)

- Pelaku, urutan, waktu, karakter kegiatan (jenis pengguna dan sifat kegiatan)

b. Aspek teoritis (teori umum, teori khusus, pola susunan, penataan, persyaratan fungsi ruang, tapak, bangunan, standar besaran ruang, ketentuan (umum dan khusus) sebagai dasar penyusunan proyek.

c. Aspek peraturan (peraturan Menteri, peraturan daerah, tata cara, kode etik)

d. Aspek sistem (sistem struktur, sirkulasi dan elemen, utilitas dan elemen, pengudaran dan pencahayaan)

e. Aspek standar (standar penyediaan, kelengkapan, pengguna fungsi, perawatan).

\section{DISKUSI DAN HASIL :}

\section{Tinjauan Lokasi Proyek}

Dari sisi perekonomian, Kecamatan Cakung merupakan kawasan khusus industri, karena kegiatan di sektor industri sangat dominan. Di kecamatan ini terdapat pabrik-pabrik besar ( berat ) maupun kecil ( ringan dan industri rumah tangga ) yang menghasilkan berbagai macam produk. Kegiatan industri terbesar terdapat di kawasan industri Pulogadung (PT. JIEP) dan kegiatan industri lainnya.

Kawasan Industri Pulogadung (JIEP) diketahui merupakan kawasan industri terbesar No. 3 di Indonesia PT JIEP sebagai pengembang dan pengelola kawasan industri pertama di 
Indonesia yang dimiliki oleh Negara RI dan Pemprov DKI Jakarta serta berlokasi di DKI Jakarta dengan luas lahan 500 ha dan memiliki lebih dari 400 perusahaan yang berlokasi di Kawasan Industri Pulogadung (JIEP).

Peruntukan Lahan : Perkantoran (K1)

$\begin{array}{ll}\text { KDB } & : 40 \% \\ \text { KLB } & : 1,6 \\ \text { KB } & : 4 \\ \text { KDH } & : 35 \% \\ \text { KTB } & : 50 \% \\ \text { Luas Lahan } & : 12.000 \mathrm{~m}^{2} \\ \text { Alamat tapak } & : \text { Jl. Raya Bekasi No.18, } \\ \text { Cakung Barat, Jakarta Timur }\end{array}$
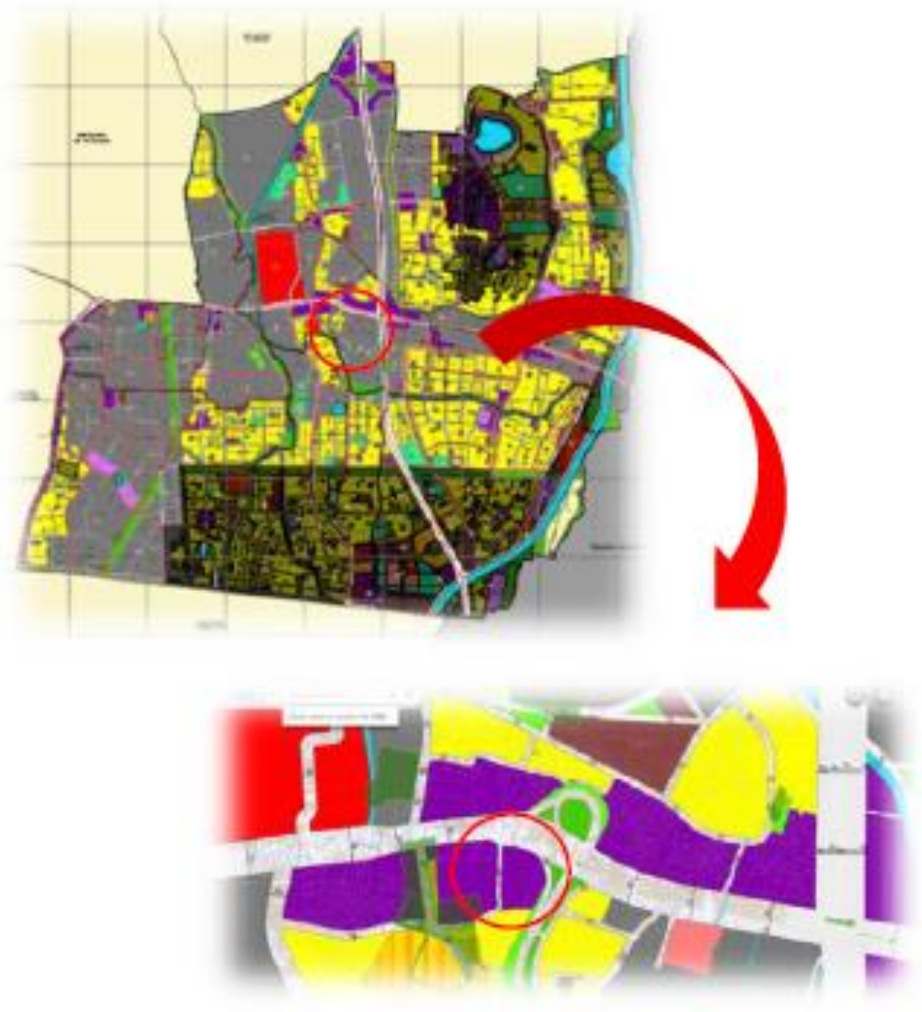

Gambar 1. Lokasi Tapak Terpilih

Sumber : tataruang.Jakarta.go.id:2019

\section{Potensi/ Peluang, dan Konflik}

Potensi/Peluang :

- Lokasi terletak dipinggiran kota Jakarta dengan jumlah industri terbanyak di DKI Jakarta

- Lokasi Strategis dekat dengan pintu tol gerbang masuk Jakarta dari arah timur yaitu Provinsi Jawa Barat ( Bekasi )

- Tapak berada di Jalan Protokol Jl. Raya Bekasi. Jalan ini dilewati kendaraan bermotor roda dua sampai mobil truk dan alat berat, dan kendaraan umum bus serta angkot.

- Lokasi tapak sendiri ada di hook lampu merah akses keluar pintu tol Cakung Barat 
- Kecamatan Cakung ini juga di lintasi oleh jalan tol cakung - Cilincing ( Cacing ) Mudah dalam pencapaian dengan kendaraan Pribadi maupun kendaraan umum (angkot dan busway)

- Memunculkan aktivitas baru dijalur sekitar lokasi, karena lokasi sebenarnya strategis tetapi hanya dilintasi kendaraan yang lalu Lalang saja (kurang diperhatikan keberadaannya)

- Meminimalisir peluang kriminal yang ada di lingkungan sekitar. Penambahan street furniture seperti : lampu jalan saat malam hari, pohon-pohon sepanjang jalur sungai agar tidak panas, bangku untuk duduk, penataan linkage jalur sekitar khususnya bagi pejalan kaki dan pesepeda.

- Dekat dengan Kawasan Jakarta Garden City, yang nantinya juga berdiri IKEA. Hal ini memungkinkan perkembangan industri di Kecamatan Cakung Timur kedepannya akan semakin pesat.

Konflik

- Minim aktivitas selain dari kendaraan yang lewat di jalan depan tapak sehingga sangat sepi di lingkungan sekitar.

- Banyaknya kendaraan besar yang lewat seperti bus, truk, dan tronton menyebabkan macet di jam-jam tertentu di sekitar tapak.

- Peluang kriminal besar, karena di sekitar tapak kurang aktivitas / kurang diperhatikan.

- Masih terdapat lingkungan perumahan kumuh di sekitar tapak.

- Masih kurangnya street furniture dan ruang terbuka hijau berupa square/plaza di sekitar lokasi tapak sehingga terlihat gersang dan monoton.

\section{Konsep Program}

Konsep program yang akan dikembangkan :

- Mencari potensi manusia beserta potensi lingkungan dari suatu area/kawasan yang memiliki jumlah industri terbesar di Jakarta

- Mencari standar ruang berdasarkan kegiatan manusia yang dilakukan sesuai dengan tempatnya

- Pembagian zoning yang teratur sehingga tidak tercipta sirkulasi yang kaku

- Membuat karakter bangunan bukan hanya pusat pelatihan kerja namun juga sebagai sarana penghubung dengan pekerjaan dan tempat kerja (industri) yang akan didapat nantinya

- Menjalin silahturahmi terhadap tempat pelatihan kerja yang lainnya

\section{Jenis Kegiatan}

Pelatihan dan Pengajaran : Kegiatan Utama dalam proyek dimana aktivitas berlangsung secara rutin dan terjadwal, kegiatan ini memberikan pelatihan secara teori maupun praktek kepada anggota pelatihan.

Supporting Activities : Kegiatan yang dilakukan dalam proyek guna mendukung kegiatan proyek yang memberikan daya Tarik dan sebagai penunjang dari kegiatan pelatihan (contoh = Pelatihan Otomotif $=>$ Bengkel)

Work Display : Kegiatan yang dilakukan untuk dapat mempresentasikan hasil dari pelatihan kepada masyarakat, aktivitas ini biasanya dilakukan secara berkala setelah 1 sesi latihan berakhir.

Service : Aktivitas yang ada sebagai pelengkap dari suatu proyek (Contoh = Area Makan, Area Komunal, Area Sirkulasi, Parkir, DLL). 


\section{Presentase Aktivitas}

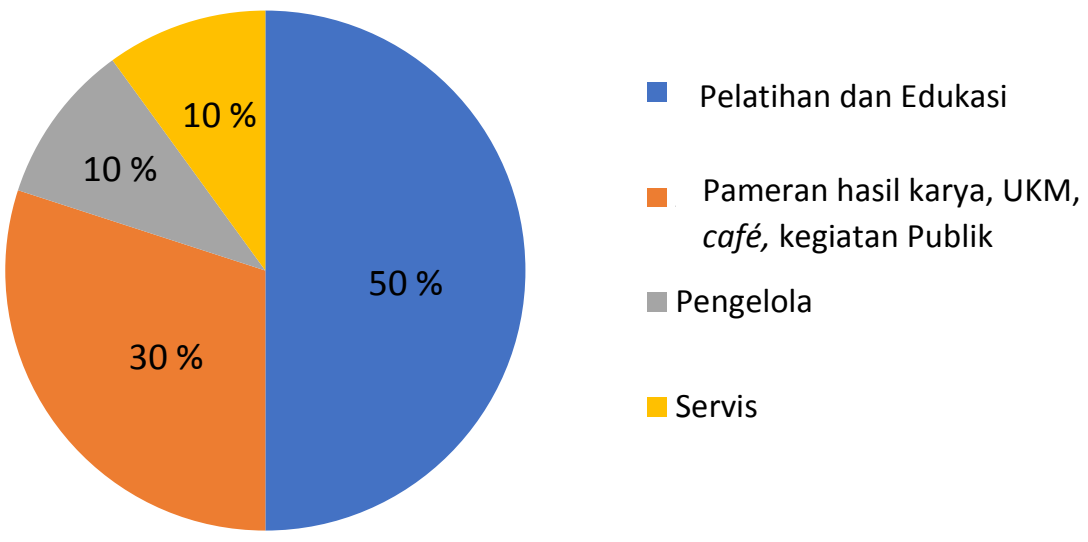

Gambar 2. Presentase Aktivitas Sumber: Penulis, 2019

\section{Konsep Rancangan Proyek}
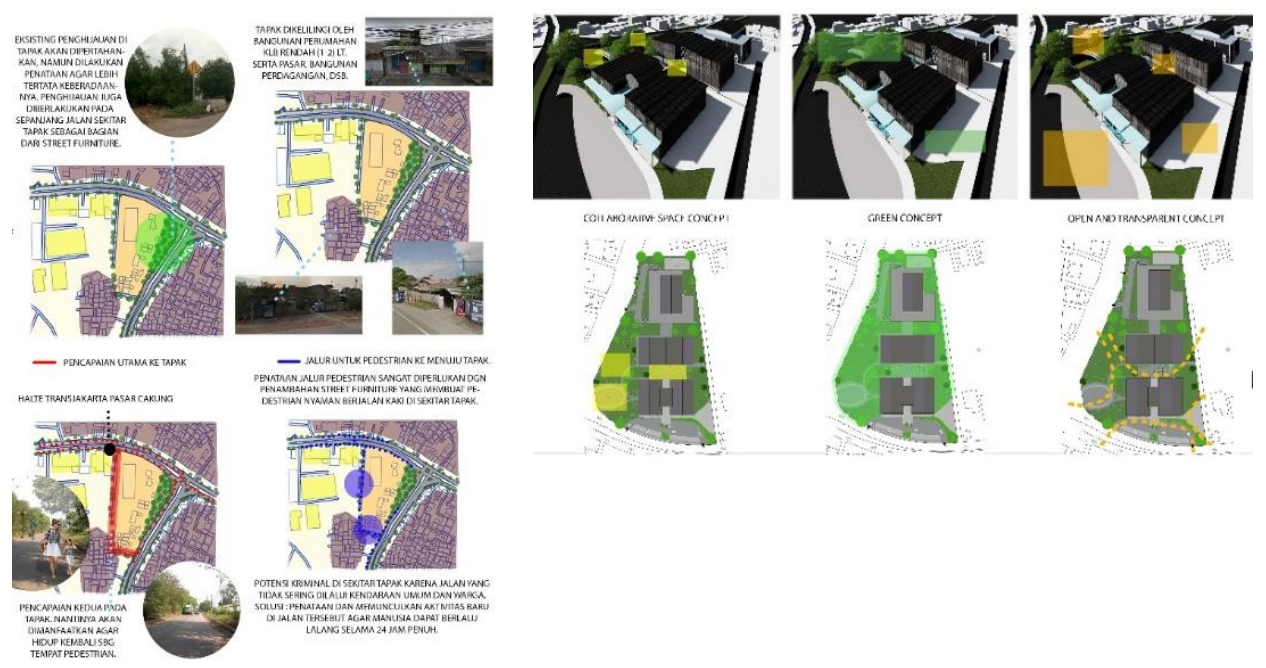

Gambar 3. Konsep Proyek

Sumber : Penulis, 2019

\section{Hasil Rancangan Proyek}

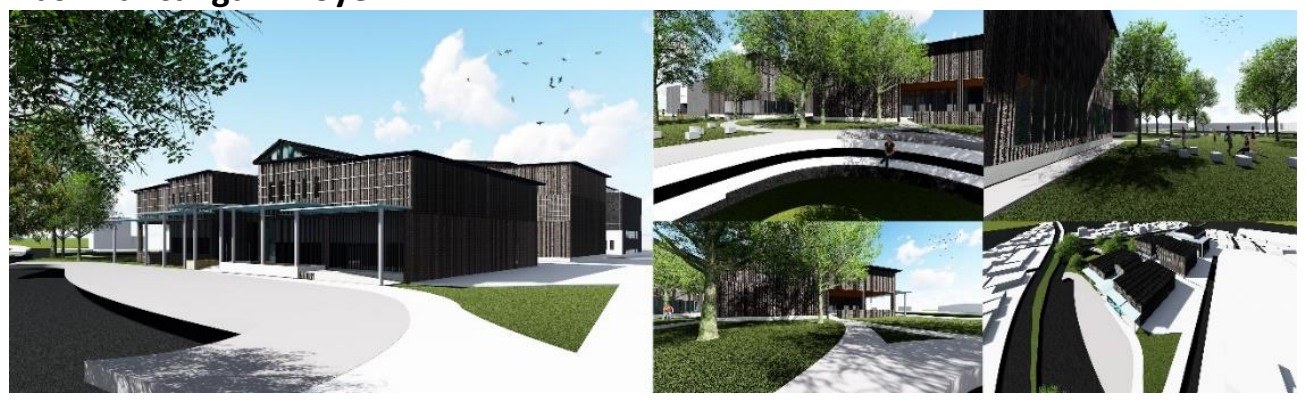

Gambar 4. Eksterior Tempat Pelatihan Industri Konveksi di Cakung Sumber : Penulis, 2019 
Hasil Rancangan proyek Tempat Pelatihan Industri di Cakung ini merupakan bangunan 3 massa dengan ketinggian maksimal salah satu massa adalah 4 lantai, massa yang lainnya 3 lantai dan 2 lantai. Pada lantai 1 dapat diakses untuk umum (open and transparent concept), kegiatan ruang luar (collaborative space concept) berupa ruang terbuka hijau, amphi theatre, work display outdoor. Ruang kegiatan lantai 1 di dalam bangunan terdiri dari restauran indoor dan outdoor, work display, lounge, mini market, retail dan ruang kelas praktek. Lantai 2 dan 3 merupakan ruang kelas teori dan praktek. Lantai 4 terdapat ruang audio visual.

Berdasarkan hasil analisis data dan konsep perancangan proyek terhadap zona tapak dan massa bangunan diperoleh desain perancangan proyek sebagai berikut :
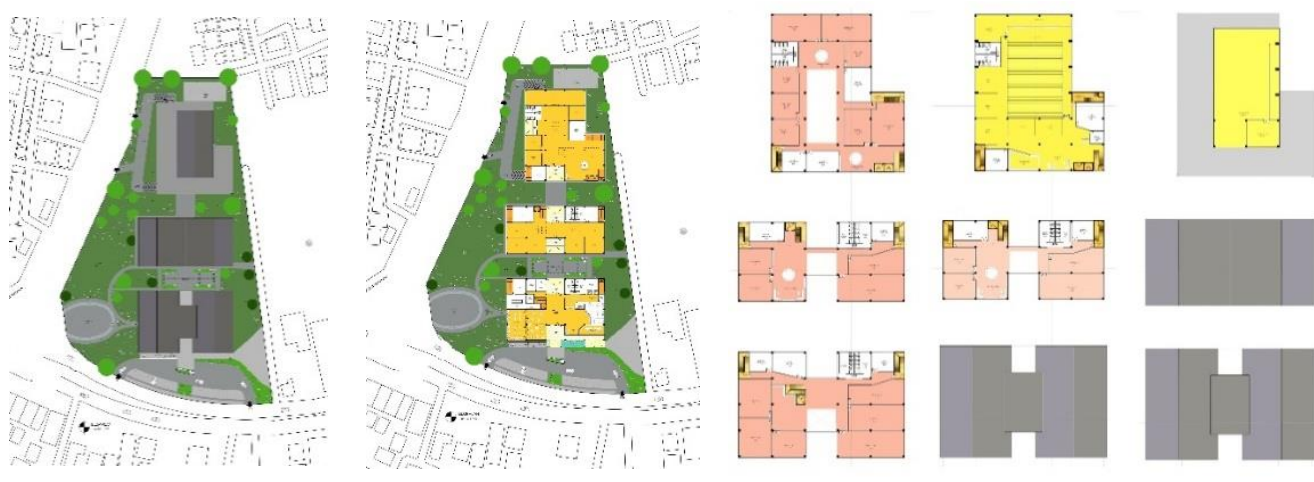

Gambar 5. Blok Plan, Denah LT 1-4

Sumber : Penulis, 2019

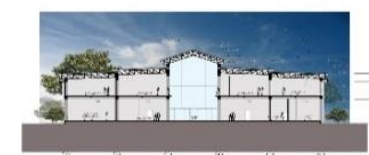

4 POTONGANA

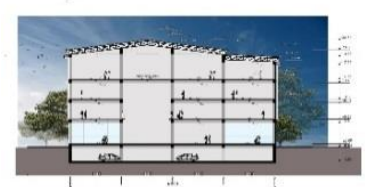

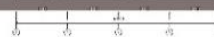

4 POTONGaAN D-
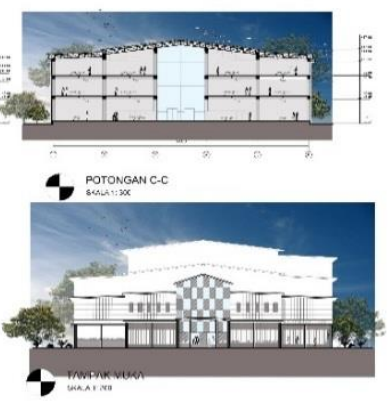

Gambar 6. Potongan danTampak Muka

Sumber : Penulis, 2019

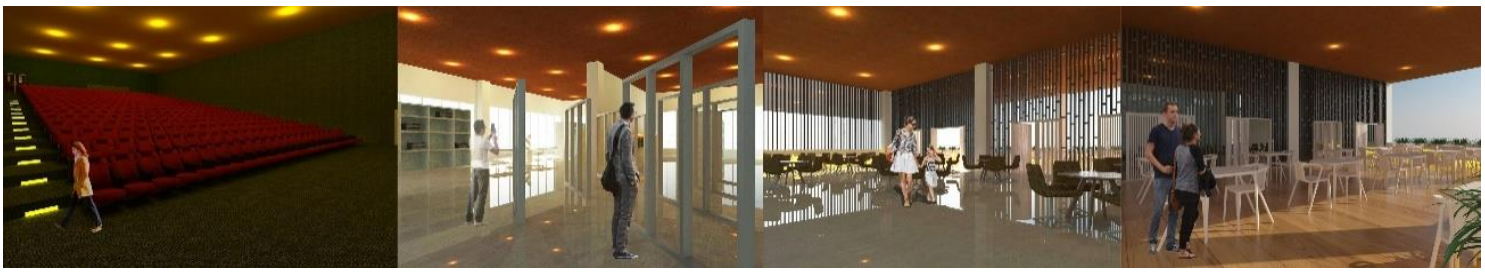

Gambar 8. Perspektif Interior

Sumber : Penulis, 2019

\section{KESIMPULAN DAN SARAN}

Generasi millennials punya tantangan menyambut Revolusi Industri 4.0 dan bonus demografi tahun 2030. Menyambut tahun 2020-2030 sebagai puncak tahun bonus demografi di Indonesia tentunya adalah menyambut peluang yang sangat besar untuk 
kemajuan dan pertumbuhan ekonomi di Indonesia. Sebelum memasuki tahun 2020, Generasi millennials sebagai populasi atau kelompok umur yang akan menjadi bonus ini sudah menunjukkan keunggulan dan kehebatannya melalui aksi nyata, khususnya pengoptimalan teknologi dan digital.

Dengan adanya generasi millennials yang terus tumbuh dan berkembang, akan ada banyak manfaat khususnya dalam bidang ekonomi yang akan didapatkan oleh Indonesia. Salah satu dampak terbesarnya adalah semakin minimnya pengangguran dan terbukanya banyak lahan pekerjaan baru bagi masyarakat Indonesia, yang bisa jadi tidak ada lahannya di masa-masa sebelumnya.

Era Revolusi Industri keempat sebenarnya sedang Indonesia tapaki yang ditandai dengan digitalisasi. Contohnya, dari sistem belanja daring sampai pembayaran uang elektronik (emoney). Tak hanya itu, perubahan di dunia digital begitu marak terjadi di nusantara. Populasi penduduk Indonesia saat ini mencapai 262 juta orang. Lebih dari 50 persen atau sekitar 143 juta orang telah terhubung jaringan internet sepanjang 2017, setidaknya begitu menurut laporan teranyar Asosiasi Penyelenggara Jasa Internet Indonesia (APJII).

Kemajuan-kemajuan teknologi seperti artificial intelligence, advance robotic, 3D printing, virtual reality, hingga cloud computing, menurut Presiden, memiliki dua sisi. Pertama, sebagai tantangan yang perlu dihadapi dan diantisipasi, dan kedua sebagai peluang yang harus diketahui dan dimanfaatkan dengan baik. Menghadapi revolusi industri 4.0, Pemerintah Indonesia melalui Kementerian Perindustrian telah mencanangkan "Making Indonesia 4.0" sebagai upaya merumuskan peta jalan atau roadmap mengenai strategi Indonesia dalam memasuki fase industri yang baru. Saat ini pemerintah fokus di industri yang jadi pendorong perkembangan revolusi industri 4.0, yakni makanan dan minuman, elektronik, otomotif, tekstil, dan kimia.

Kecamatan Cakung sebagai kawasan industri terbesar no.3 di Indonesia dinilai dapat menjadi lokasi proyek yang mana bila dilihat perkembangannya dari dahulu yaitu kawasan industri pulo gadung (PT. JIEP) dan Perkampungan Industri Kecil (PIK), sampai saat ini berdiri AEON Jakarta Garden City dan segera disusul IKEA, menandakan sektor industri di kecamatan Cakung berkembang pesat.

Dari sisi perekonomian, Kecamatan Cakung merupakan kawasan khusus industri, karena kegiatan di sektor industri sangat dominan. Di kecamatan ini terdapat pabrik-pabrik besar (berat) maupun kecil ( ringan dan industri rumah tangga ) yang menghasilkan berbagai macam produk. Kegiatan industri terbesar terdapat di kawasan industri Pulogadung (PT. JIEP), Perkampungan Industri Kecil (PIK), dan kegiatan industri lainnya.

Sebesar 24,33\% luas lahan di kecamatan ini, adalah untuk industri. Masyarakatnya bekerja paling banyak di sektor perdagangan dan industri. Menurut data yang diperoleh pada kecamatan Cakung, salah satu industri terbesar adalah industri pakaian jadi. Proyek Tempat Pelatihan Industri Konveksi di Cakung ini diharapkan mampu meningkatkan mutu sumber daya manusia dan mempersiapkan generasi millennial untuk menghadapi masa yang akan datang yaitu fenomena tahun Bonus Demografi dan Era Revolusi Industri 4.0 yang sudah ada di depan mata.

Di Jakarta sendiri sudah terdapat 7 (tujuh) Balai Latihan Kerja (BLK). Akan tetapi, dirasa masih kurang mumpuni untuk menjawab perkembangan jaman karena kurikulum yang dipakai adalah kurikulum lama, dan hampir sama antara BLK satu dan yang lainnya. Kurangnya ketersediaan lading pekerjaan pada wadah perusahaan yang menjadi koneksi dari BLK tersebut, sehingga hanya sekitar $30 \%$ dari lulusan BLK yang bekerja di perusahaan koneksi. Hal ini dirasa perlu adanya Tempat Pelatihan lain yang lebih up to date dan dapat membaur dengan fenomena dan generasi millennials saat ini juga masa depan.

Dari alasan itu akhirnya Penulis merencanakan mendesain Tempat Pelatihan Industri Konveksi di Cakung yang selain menyalurkan tenaga kerja ke perusahan akan tetapi juga 
memberikan wadah kerja bagi mereka lulusan tempat pelatihan ini yang ingin bekerja, sehingga konsep bangunan Tempat Pelatihan Industri Konveksi di Cakung ini adalah TRAINING, EDUCATION, AND WORK PLACE dimana bangunan ini menggabungkan 3 fungsi yaitu pelatihan, pembelajaran, dan tempat untuk bekerja.

\section{REFERENSI}

Tjahyono, G. (1998). Metode Perancangan Suatu Pengantar Ruang Untuk Arsitek dan Perancang

Tsukamoto, K. (2010). Behaviorology. Tokyo : Random House Incorporated

Vidler, A. (1977). The Third Thypology. UK: Actarbirkhauser

https://ideannisa.com/2017/05/04/peluang-ekonomi-bonus-demografi-millenial/

https://www.kompasiana.com/andhinirosari/5a2e2c4acf01b4574160ed32/bonus-demografidan-dampak-terhadap-indonesia?page=all

https://kumparan.com/@kumparannews/jokowi-indonesia-mendapat-bonus-demografitahun-2020-sampai-2030

http://www.tribunnews.com/nasional/2018/09/28/kaum-millenials-berperan-dalamperkembangan-revolusi-industri-40.

http://jatim.tribunnews.com/2018/11/11/choirul-tanjung-paparkan-tantangan-generasimillennial-di-era-revolusi-industri-40? page $=2$.

https://ruangmahasiswa.com/lifestyle-trend/generasi-milenial/

https://jakartasatu.jakarta.go.id/

https://id.wikipedia.org/wiki/Cakung,_Jakarta_Timur

https://jaktimkota.bps.go.id/publication/2018/09/26/fb16984a4478a23208f5bfa3/kecamatancakung-dalam-angka-2018.html

https://www.archdaily.com/519078/i-am-recycled-pkmn-architectures

https://www.archdaily.com/625914/towada-community-plaza-kengo-kuma-and-associates https://www.archdaily.com/882662/golkar-jakarta-office-delution-architect/ https://www.archdaily.com/497410/unc-coastal-studies-institute-clark-nexsen https://www.archdaily.com/769089/new-leather-workshop-in-the-isere-department-jeanfrancois-schmit 